\title{
MULTIDIMENSIONAL POVERTY IN PAKISTAN: A POLICY PERSPECTIVE
}

\author{
Hummera Saleem ${ }^{1 *}$ and Muhammad Bilal Khan ${ }^{2}$ \\ ${ }^{1}$ Department of economics, Wuhan University, China \\ ${ }^{2}$ Department of Accounting, Wuhan University, China
}

\begin{abstract}
Mostly poverty related researches have only explored monetary poverty. This empirical analysis reveals the International Multidimensional Poverty Index estimations for Pakistan. The statistical data has been gathered from the statistical Survey of "Pakistan Social and Living Standard Management" (PSLM). The Alkire and Foster $(2010,2014)$ methodology is used in this empirical analysis due to its instinctive and appropriate properties for policy making. The five provinces of Pakistan (including rural and urban regions) are taken such as Punjab, Sindh, Baluchistan and Khyber Pakhtunkhwan. Using PSLM statistical surveys data, we found that Pakistan's global multidimensional poverty (MDPT) index value is 0.292 points in $2004 / 05$, decreases significantly to 0.197 in 2014-15, while the headcount (HD) ratio dropped from $55.2 \%$ to $38.8 \%$ with $(16.4 \%$ difference).Finding of this analysis shows that during all time periods multidimensional poverty (MDPT) of Pakistan remained significantly higher in rural areas as compared to urban areas. This empirical analysis provides that an integrating technique adopting for MDPT to overcome the socioeconomic issues rapidly in Pakistan because it is basic requirement of millennium and sustainable development goals (MDG's) to provide basic necessities of life (e.g., food, health, water, and education) to meet the Global standards of wellbeing.
\end{abstract}

Keywords: Poverty, health, education, welfare.

JEL CLASSIFICATION: I132, P46

\section{Introduction}

In Pakistan Multidimensional poverty (MDPT) index has been used to identify socio-economic factors which increase development process with minimize poverty ratio and meet the requirements of Vision (2015) and identify various social goals. Pakistan's MDPT index tries to fulfill the requirements of Pakistan's vision 2025. To encourage the growth process, monitoring and readapting programming, providing policy for effective governance as well as designing and targeting integrating policies are the main functions of MDPT index. The key objective of Pakistan's Vision (2025) is to achieve significant and sustainable growth and development to minimize the deprivations from economy. Poverty in Pakistan is Multidimensional, covering not only money deficiency based poverty but also the deficiency of hospitals and healthcare facilities in the country, high rate of illiteracy and various social issues for whole population across the country. Pakistan's commitment to eradicate poverty report explores that national MDPT based on the method of Alkire-Foster (AFS), from in this report we take statistical data of PSLM various survey to estimate MDPT in the Pakistan, this survey also estimate the impact of socio-economic indicators and dimensions to MDPT (Government of Pakistan 2016).

There is prerequisite of wellbeing to realize the main indicators of deprivation through economic as well as social aspects and issues are related to poverty (Bourguignon \&Chakravarty, 2003). The famous Chronic Poverty Research Center explore that deprived condition of the people cannot be measured through lowness of income rather it has numerous manifestations such as hunger and malnutrition, absence of health facilities, inadequate income and productive resources, inadequate educational facilities, and many other basic services, and mortality from illness, increased morbidity, and lack of shelter, unsafe and unhealthy environmental conditions, social exclusion and marginalization (CPRC, 2004). To fulfill the all financial requirement the 
income is being a partial proxy explains as only necessary condition but not a sufficient indicator of welfare of the people that just deals with one pillar for attacking deprivation. Pakistan as a developing country thus there is need to reshaped anti-poverty policies and there is need such policies which minimize the poverty ratio from country, but has not yet accurately applied MDPT the measurement. So, in this article we try to adopt the Alkire-Foster methodology to fill the gap.

The remaining sections describe the details of paper. Section (2) represents the conceptual framework. Section (3) relates to the literature review. Section (4) presents methodology and empirical analysis of the study. The findings of this empirical study are mentioned in Section (5). Section no (6) based on conclusion and discusses the policy suggestions and implications.

\section{Conceptual Frameworks}

\section{The main Concept of Poverty}

Theoretically, this study is based on the approach of AmartyaSen's Capability (ASC) which described that deprivation is multidimensional concept in nature (Sen, 1999). Poverty is not a single aspect as it contains multiple aspects so measurement of poverty in only monetary term cannot be beneficial (Ravallion, 2011b) and various empirical analyses found. It is not necessary that improvement of welfare is related to economic growth (Ahluwalia, 2011). Khilji $(2014,2015)$ stressed on policy makers to design various appropriate economic policies, programs for poverty reduction which is essential to understand the main concept of poverty. However, poverty is multidimensional, diverse and narrow dimensional concept (see, Misturelli and Heffernan 2010). The economic deprivation in terms of money and deficiency of financial resources to access the basic necessities are the main aspects of poverty and according to prior literature that minimum level of consumption and basic necessities are needed for a healthy life (Lipton 1997). According to World Bank (2011) modern monetary definition of poverty is about USD $\$ 1.90$ a day in line (with inflation), this relates to the consumption and income level of the people and assumes that financial deficiencies facing by the poor and this are the main reason of poverty.

The Alkire\& Santos (2010) explained that the concept of multidimensional poverty is broadly acknowledged by recent socio-economic literature, because globally, more than 114 million children have not facilities of basic education, and illiteracy rate of women is also more than 584 million. The $42 \%$ of the world population and more than $20 \%$ south Asian countries are facing the problem of clean drinking water, toilet and many other inefficient basic necessities of life (UN Millennium Project, 2002), further major contribution has been done by the Alkire\& Santos (2010), who revealed that the concept of multidimensional poverty is broadly acknowledged by recent socio-economic literature, because globally, more than 114 million children have not facilities of basic education, and illiteracy rate of women is also more than 584 million.

A strong theoretical foundation is given by the Millennium Development Goals (MDGs) and Sustainable Development Goals (SDGs), that's highly focused their attentions on human development program and poverty reduction policies. Due to theoretical development, availability of data based on micro-level and advances in methodology in last few years have provided research into measurement of poverty with its all dimensions. Angulo et al. (2016) discussed that poverty measurement is including not only money based poverty but it tries to estimate poverty with its all dimensions and aspects. Estimation of MDPT with its new measures are encouraging by Oxford Poverty and Human Development and united nation development programs (UNDP) (e.g., UNDP 1997, 2010; Alkire and Foster 2011; also Alkire and Santos 2010).

\section{Review of literature}

More than 1129 million people are living in a serious socio-economic deprivation condition, with a certain disparity in magnitude across different economies and regions (UNDP, 2013). The dilemma of deprivation of 
people has been a notable challenge in the last many decades of third world countries; it is more challengeable because it has bad influenced on the economic growth and development process. Globally , 557 million people are poor in south Asian countries, and the magnitude and rate of deprivation has risen significantly over time (UNDP, 2013). Pakistan is not free from poverty, overtime the proportion of poverty is increasing significantly (Naseem, 2012). During the period of 1990s in Pakistan, the poverty is becoming is increasing because of destabilizing policies, poor quality of governance, inflation (prices of goods and services are increasing) and slow growth rate and etc.( Haq\&Bhatti, 2001; Naseem,2012).

Various empirical analyses have employed varying indicators and dimensions to quantify MDPT (like Sahn and Stifel 2000; Mohanty 2011; than various recent studies Batana 2013; Yu, 2013; Santos 2013; Battiston et al. 2013; Hanandita and Tampubolon 2015; and finally Angulo et al. 2016). A systematic review and numerous methods have been developed for estimating MDPT (e.g., Alkire and Foster 2008; Mishra and Ray 2013; Decancq and Lugo 2013; Dehury and Mohanty 2015). The estimation of multidimensional poverty done by (e.g., Anand and Sen 1997; Bourguignon and Chakravarty 2003; then Jayaraj and Subramanian 2010; Coromaldi and Zoli 2012; Rippin 2010; Khan et al. 2015,Saboor et al 2015, Mishra and Shukla 2016,Alkire and Shen 2017). Though, empirical analysis on the application of multidimensional poverty findings remains scared (Mohanty 2011).

\section{Data and Research Methodology}

\section{Description of data}

This study tries to examine the deprivation ratio in Pakistan including its four provinces i.e., Punjab, Khyber Pakhtunkhwan, Sindh and Baluchistan and. The data was collected from PSLM survey of Pakistan for different time periods, i.e. 2004/05, 2006/07, 2008/09, 2010/11, 2012/13 and 2014/15. The data on facilities of health, education and houses are the main indicators of socio-economic aspects of the economy. These main indicators with its main 10 variables are mentioned in table (1). The years of education and ability of reading and writing are used as years of education than availability of clean drinking water, immunization and pre and postnatal consultation are used for the proxies of health facilities deprivation. Likewise, other five main variables access to electricity and telephone services, house occupancy status, and access to facilities of gas toilet in houses are used as the proxies of the deficiencies of facilities of housing.

Finally, multidimensional poverty is estimated which is based on estimated dimension levels in all provinces for five time periods.

Table 1.Details of MDPT Dimensions, main indicators and deprivation thresholds

\begin{tabular}{|c|c|c|}
\hline Dimensions & MAIN INDICATORS & Criteria used for DEP, CUT-OFF (deprived if...) \\
\hline Income (CY) & One-dimensional & $\begin{array}{l}\text { If income is less than }(<) \text { National poverty line then } \\
D=1 \text {, and } 0 \text { otherwise }\end{array}$ \\
\hline \multirow[t]{2}{*}{$\begin{array}{l}\text { Facilities of } \\
\text { Education (ED) }\end{array}$} & Years of education & If highest classis $\leq 6$ then $\mathrm{D}=1$, and 0 otherwise \\
\hline & $\begin{array}{l}\text { Reading and writing } \\
\text { ability }\end{array}$ & $\begin{array}{l}\text { If cannot read and write in any language then } \mathrm{D}=1 \text {, and } 0 \\
\text { otherwise }\end{array}$ \\
\hline \multirow[t]{3}{*}{$\begin{array}{l}\text { Facilities of Health } \\
(\mathrm{HF})\end{array}$} & Immunization/vaccination & If not immunized then $\mathrm{D}=1$, and 0 otherwise \\
\hline & $\begin{array}{l}\text { Clean drinking water } \\
\text { facility }\end{array}$ & If source of water not piped then $\mathrm{D}=1$, and 0 otherwise \\
\hline & $\begin{array}{l}\text { Pre/post-natal } \\
\text { consultation }\end{array}$ & $\begin{array}{l}\text { If did not go for any pre-natal consultation then } \mathrm{D}=1 \text {, } \\
\text { and } 0 \text { otherwise }\end{array}$ \\
\hline
\end{tabular}


Proceedings of the $4^{\text {th }}$ International Conference on Poverty and Sustainable Development, Vol. 4, 2017, pp. 35-51

\begin{tabular}{|l|l|l|}
$\begin{array}{l}\text { Facilities of housing } \\
\text { (HU) }\end{array}$ & Own House or not status & If house is not owned then $\mathrm{D}=1$, and 0 otherwise \\
\hline & Availability of electricity & $\begin{array}{l}\text { If electric connection is absent then } \mathrm{D}=1 \text {, and } 0 \\
\text { otherwise }\end{array}$ \\
\hline & Availability of gas & If gas connection is absent then $\mathrm{D}=1$, and 0 otherwise \\
\hline & $\begin{array}{l}\text { Availability of telephone } \\
\text { services }\end{array}$ & $\begin{array}{l}\text { If telephone connection is absent then } \mathrm{D}=1 \text {, and } 0 \\
\text { otherwise }\end{array}$ \\
\hline & Toilet facility & $\begin{array}{l}\text { If flush not connected to public sewerage/pit then } \mathrm{D}=1, \\
\text { and } 0 \text { otherwise }\end{array}$ \\
\hline
\end{tabular}

Sources: Pakistan Social and Living Standard Management Survey (PSLM)

Note: Dep=Deprivation

\section{Methodology of the Study}

The methodology of MDPT study is divided into two different segments i.e. multidimensional headcount ratio and identification. So, MDPT can be measured with various available methods; the choice of methods depends upon the data and its type and context of segregation. The study used AFS methodology designed by (Alkire and Foster, 2010, 2015) because of its instinctive and appropriate properties of policy. The AFS approach with its various benefits is now getting popularity and with its various dimensions to decompose poverty, so that's why the AF method is being used here. The aggregation phases (methodology of headcount ratio) and identification or dual cut-off method are two main segments of MDPT. The aggregation method is related to the knowledge of the deprived persons and thus poverty line which explains the poverty at the combined platform. However, the identification system first depends upon the difference between the poor and non-poor people are mentioned in all dimension and secondly, to check about the poor from non-poor people across the domain than the identification is applied (Alkire\& Foster, 2008).

The methodology of AFS provides comprehensive information about the three significant indices of MDPT .i.e., the head count ratio (HD) of MDPT, the intensity of poverty (IA) and finally the MDPT Index (Alkire and Foster 2015). The equations are given below,

The percentage of poor persons of the country's population is denoted by the ratio of headcount (HD), following equation based on total numbers of deprived person.

$$
\mathrm{HD}=\mathrm{tq} \div \operatorname{tn}
$$

Where tq indicates the total number of deprived persons in the economy and th is related to total population.

The intensity (IA) of MDPT denotes as the average weighted deprivation practiced by the poor people and is described as

$$
\mathrm{IA}=\sum \mathrm{c}_{\mathrm{i}}(\mathrm{k}) \div \mathrm{tq}
$$

Where the censored deprivation is symbolized as $c_{i}(k)$ and the number of deprived people or multidimentionally poor people is symbolized as tq.

The multiplication of HD and IA represents the MDPT index

$$
\mathrm{MDPT}=\mathrm{HD} * \mathrm{IA}
$$

Where, index of MDPT shows the proportion of the total number of multidimensional. 
Different indicators with its significant contribution to the MDPT

$w_{\mathrm{i}}^{*} *$ censored headcount ratio ${ }_{\mathrm{i}} *$ MDPTINDEX $_{\text {country }} * 100$

Where, $w_{i}$ indicates as the weight of the indicator (ith)

This analysis used the structure of equal weighting among the significant magnitudes of deprivation i.e. education, health and housing services, across various attributes (above mentioned domains) due to the nonavailability of suitable justification. The problems of basic necessities of the life can be discussed as multidimensionally with a suitable solution to the weighting methodology (Saboor et al 2015). Kruijk and Rutten (2007) explained that the adoption of weights preferably demonstrates the relative significance of the various features among the sets of attributes. Thus the different dimensions of deprivation allows the investigators to use these dimension separately (with control the weights) (Noble et al 2009). It is important to find suitable direction to put proper weights to each domain otherwise putting more weights to one dimension as compared to another dimension will not be rational (see Deutsch, \& Silber, 2008; Foster, 2007).

\section{Identification stage}

Dual cut-off method is described in this phase where deprivation threshold identification explains person is poor or not poor in $1^{\text {st }}$ phase, Table (1) explains the different achievement level of deprivation are regularized that for deprived person with the positive (non-zero) values indicates as " 1 and then " 0 " shows otherwise. Secondly, we construct vector by counting vertically each column then assigning the number of deprivation of each deprived person where sample data based on poor and non-poor peoples. The method of cut-off denotes as "kt" which relates to deprived person that should be greater than or can be equal to the "kt". To identify the dimension of poverty there is essential to estimate kt which can be estimated by dividing the number of dimensions by 2 (Naveed\& Islam, 2010).

\section{Robustness of Estimates}

By setting the kt point of the weighted deprivation the MDPT can be measured. The kt ratio of deprivation is fixed at 33.3\% (with its three dimensions) globally and Pakistan also. The level of multidimensional poverty decline when the value of $\mathrm{kt}$ is increased. If score of deprivation of individuals equal or more than the values of $33.3 \%$ those will be considered as multidimensionally deprived person. The person will not be identified multidimensional poor if his/her score doesn't exceed 33.3\%. Before setting the points of cut-off, this analysis carried out a robustness test (shown in figure 1) by different values of kt for Pakistan in different years. When the $\mathrm{kt}$ value fixed at $33.3 \%$ the value of multidimensional (MDPT index is dropped from 0.292 in 2004-05 to 0.197 in 2014-15. Pakistan tackled statistically significantly declines in its poverty (MDPT).

To find the main significant indicators of MDPT, this study used a logistic regression model (logit model) for Pakistan. In this logistic model the dependent variable was the grouping of family member constructed on MDPT, i.e. is a person is multidimensionally deprived or not poor (denoted as " 0 " if the person is multidimensionally none deprived and 1 if the individual is deprived.). The following model is followed by (Mohanty et al 2017). 
Following equation represents the regression model,

Multi_dimentional poor $=\alpha+\beta_{1}$ resi $_{1}+\beta_{2}{\operatorname{sex} \_h h l_{1}+\beta_{3} \text { age_hhl }}_{1}+\beta_{4}$ educ_hhl $_{1}+\beta_{5} \operatorname{size}_{-}$hhl $_{1}+\beta_{6}$ cons $_{1}+$ $\beta_{7}$ deat $_{1}+\beta_{8}$ relig $_{1}+e_{1}(5)$

Where the intercept is denoted as $\alpha$, Multi_dimentional poor ${ }_{i=1}$ is defined as multidimensional poverty. Sex_hhli is described as the sex(male/female of head of household. resi is residence (population lives in rural or urban regions) The age of the head of family is denoted by the education of head of family is denoted as educ_hhli,

size_hhli related to the size of household, ${ }^{\operatorname{cons}_{\mathrm{i}} \text { relates to the consumption of the household }}{ }^{z}$ if any person of the family has been died in last one is symbolized as ${ }^{\text {deat }_{\mathrm{i}}}$, year, religion of the head of family is defined as relig $_{i}$ and i subscript is applied for ${ }^{\text {th }}$ household.

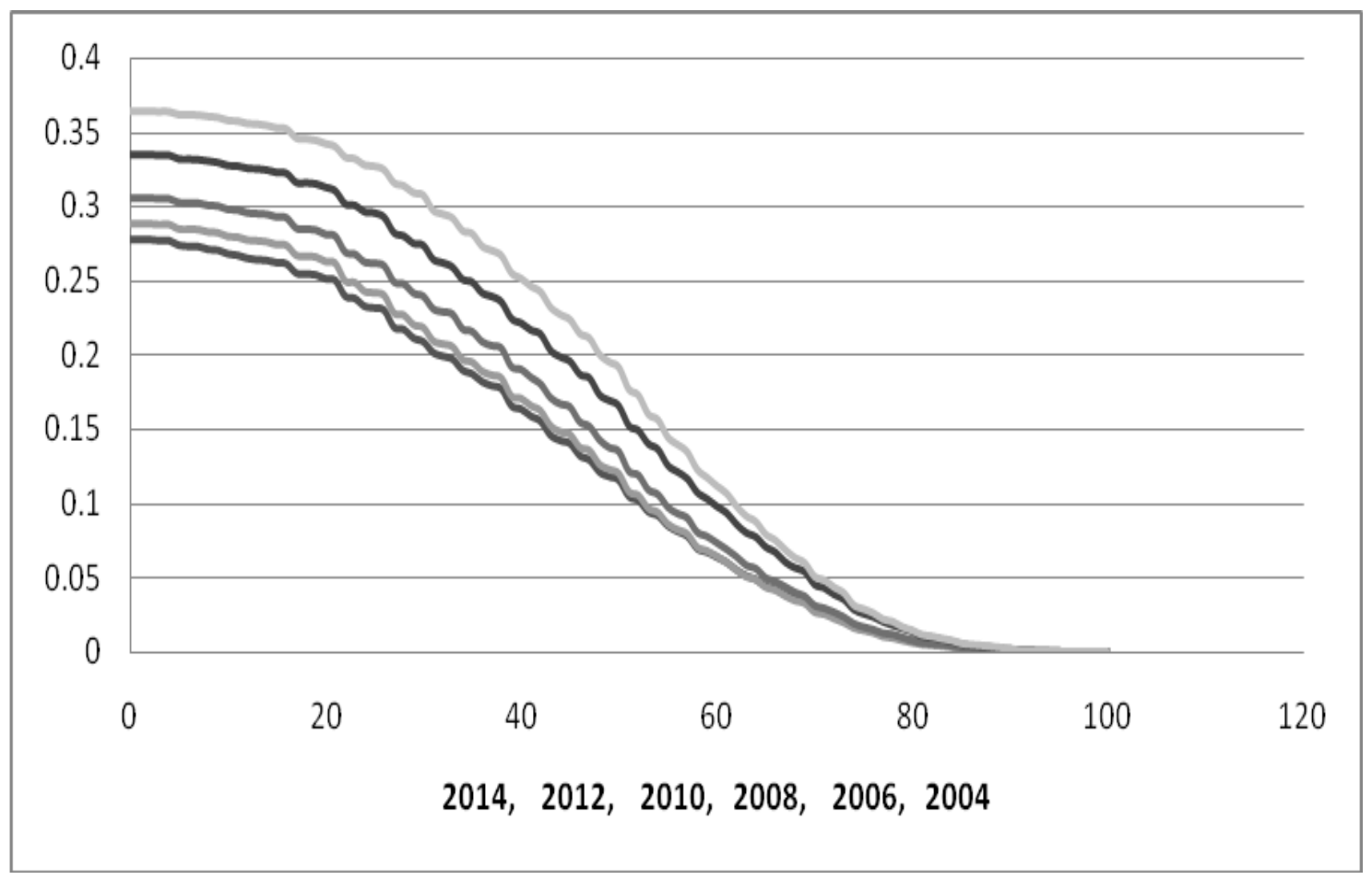

Figure 1. MPI (\%) in Pakistan for different values of kt, 2004 to 2014

Source: Statistical data is taken from PSLM (2016). 


\section{Empirical Results}

\section{Pakistan's Regional MDPT Results}

Table: 2 Results of Headcount MPI rate (\%)

\begin{tabular}{|c|c|c|c|c|c|c|c|}
\hline & & 2004-05 & 2006-07 & 2008-09 & 2010-11 & $2012-13$ & $2014-15$ \\
\hline \multirow{3}{*}{$\begin{array}{l}\text { At National } \\
\text { level }\end{array}$} & Overall & 55.2 & 52.5 & 49.3 & 46.5 & 40.8 & 38.8 \\
\hline & Urban & 24.0 & 19.4 & 17.3 & 13.9 & 10.1 & 9.3 \\
\hline & Rural & 70.3 & 69.5 & 65.2 & 62.3 & 56.0 & 54.6 \\
\hline \multirow[t]{3}{*}{ Punjab } & Overall & 49.7 & 46.4 & 43.2 & 40.0 & 34.7 & 31.5 \\
\hline & Urban & 19.7 & 16.1 & 13.2 & 11.0 & 8.4 & 6.3 \\
\hline & Rural & 62.7 & 61.0 & 57.0 & 53.4 & 46.9 & 43.9 \\
\hline \multirow[t]{3}{*}{ Sindh } & Overall & 57.3 & 53.7 & 51.2 & 49.5 & 44.6 & 43.2 \\
\hline & Urban & 27.2 & 19.6 & 20.0 & 14.9 & 10.9 & 10.5 \\
\hline & Rural & 88.1 & 87.4 & 81.0 & 79.9 & 75.5 & 75.7 \\
\hline \multirow{3}{*}{$\begin{array}{l}\text { Khyber } \\
\text { Pakhtunkhwa } \\
(\mathrm{KPK})\end{array}$} & Overall & 65.8 & 66.1 & 66.1 & 57.0 & 49.1 & 49.1 \\
\hline & Urban & 30.5 & 32.9 & 23.2 & 19.2 & 10.0 & 10.2 \\
\hline & Rural & 72.9 & 72.8 & 68.0 & 64.8 & 57.1 & 57.7 \\
\hline \multirow[t]{3}{*}{ Balochistan } & Overall & 83.4 & 79.8 & 78.9 & 76.7 & 71.9 & 71.0 \\
\hline & Urban & 49.4 & 42.6 & 40.1 & 37.2 & 29.0 & 37.4 \\
\hline & Rural & 91.6 & 91.9 & 90.7 & 89.3 & 85.8 & 84.5 \\
\hline
\end{tabular}

Source: Researcher own calculations based on data collected.

Table (2) reports the provincial disparities in Pakistan, urban areas are less deprived as compare to rural areas. The results at province level indicate that Baluchistan with highest MDPT in while Punjab has the lowest incidence.

\section{Pakistan's Global MDPT Results}

Table: 3. Multidimensional Poverty by Region in Pakistan,2014-15

\begin{tabular}{|l|l|l|l|l|}
\hline Provinces & & Values & & \\
\hline & & MPI values & H(Incidence) & A(Intensity) \\
\hline Punjab region & Total & 0.152 & $31.40 \%$ & $48.40 \%$ \\
\hline & Urban & 0.026 & $6.30 \%$ & $41.80 \%$ \\
\hline Sindh region & Rural & 0.214 & $43.70 \%$ & $48.90 \%$ \\
\hline & Total & 0.231 & $43.10 \%$ & $53.50 \%$ \\
\hline & Urban & 0.046 & $10.60 \%$ & $43.40 \%$ \\
\hline
\end{tabular}


Proceedings of the $4^{\text {th }}$ International Conference on Poverty and Sustainable Development, Vol. 4, 2017, pp. 35-51

\begin{tabular}{|l|l|l|l|l|}
\hline KPK region & Total & 0.25 & $49.20 \%$ & $50.70 \%$ \\
\hline & Urban & 0.042 & $10.20 \%$ & $41.50 \%$ \\
\hline & Rural & 0.295 & $57.80 \%$ & $51.10 \%$ \\
\hline Balochistan & Total & 0.394 & $71.20 \%$ & $55.30 \%$ \\
\hline & Urban & 0.172 & $37.70 \%$ & $45.70 \%$ \\
\hline & Rural & 0.482 & $84.60 \%$ & $57.00 \%$ \\
\hline \multicolumn{4}{l}{ Sources: PSLM survey for four provinces $(2014-15)$} \\
\hline
\end{tabular}

The intensity of poverty (IA) and headcount ratio (HD) presents for provinces, urban and rural areas OF Pakistan in table (3). The statistical figures indicate that people in rural zones are more deprived as compared to urban areas and the difference is statistically significant. Overall poverty in rural areas high and IA is higher because in Pakistan two-thirds or 180 million people live in rural areas, this difference is not closely as more as the inconsistency in the poverty HD between cities and rural regions. These results are consistent with the results of Khan et al. (2015).

Table: 4 Statistical results of (HD), (IA) and (MDPT) Index

\begin{tabular}{|c|c|c|c|c|}
\hline & Index & Value & \multicolumn{2}{|c|}{ Confidence interval at (95\% level) } \\
\hline Survey & MDPT & 0.197 & 0.189 & 0.205 \\
\hline & HD & $0.39 \%$ & $0.37 \%$ & $0.40 \%$ \\
\hline 2014-15 & IA & $0.51 \%$ & $0.51 \%$ & $51.3 . \%$ \\
\hline
\end{tabular}

Source: Authors' estimations based on the PSLM survey (2014-15)

The statistical results of Pakistan's MDPT with its population ratio are presented in table (4) for period 2014-15, with the value of its major components where HD shows as MDPT in percentage and IA represents the level of intensity of poverty. The $38.8 \%$ is the value of HD and level of confidence interval at $95 \%$ which shows that we are $95 \%$ sure that ratio HD is in between $37.3 \%$ and $40.2 \%$ (total population). The rate of average IA is $50.9 \%$ (which reveals the contribution of deprivations by each poor person), where deprived ratio (average) is approximately half of the weighted indicators. The value of MDPT (HD*IA) is 0.197 which reflects the ratio of MDPT in Pakistan experience $19.7 \%$ of the total deprivations.

Table: 5 Pakistan's national MDPT results: 2014-15

\begin{tabular}{|l|l|l|l|l|}
\hline Index & Population (in\%) & Value & \multicolumn{3}{|l|}{ Level of confidence interval (95\%) } \\
\hline & & URB & & \\
\hline MDPT & & 0.04 & 0.035 & 0.045 \\
\hline HD & $33.10 \%$ & $9.40 \%$ & $8.20 \%$ & $10.50 \%$ \\
\hline IA & & $3.10 \%$ & $42.50 \%$ & $43.60 \%$ \\
\hline & & RUR & & \\
\hline MDPT & & 0.281 & 0.273 & 0.29 \\
\hline HD & & $54.60 \%$ & & $56 \%$ \\
\hline IA & $67.00 \%$ & $51.60 \%$ & & $52 \%$ \\
\hline
\end{tabular}

Source: Authors' own estimation constructed on data from the PSLM survey (2014/15)

Table (5) shows statistical result that is estimated for the IA, MDPT, and HD ratios as (\% of population) share (including rural and urban regions) and adds the confidence intervals. 


\section{Censored and Uncensored Headcount Ratio in Pakistan}

Table (6) indicates the ratios of Censored headcount (CENHD), results show that ratio of people whom are deprived or multidimensional poor (MDPT) and who are deprived in a set of many indicators for 2012-13 to 2014-15 periods covered by the PSLM statistical data. Results show that CENHD have weakened over time in each indicator, e.g., the ownership of land and livestock (reveals deprivations increased) and especially with the exception of vaccination. The CENHD ratios of education(with its all indicators) are shown decreasing trend between the periods of 2012 and 2015. 
Table 6: Structure of Censored Headcount Ratios (CENHD) (in \%)

\begin{tabular}{|c|c|c|c|c|c|c|c|c|c|c|c|c|c|c|c|}
\hline 2012-13 & YS & SA & EQ & $\mathrm{HF}$ & FM & AN & $\mathrm{AD}$ & IW & $\mathrm{OC}$ & EL & $\mathrm{SN}$ & WA & $\mathrm{CF}$ & AS & $\mathrm{LN}$ \\
\hline National & $37.0 \%$ & $17.0 \%$ & $12.7 \%$ & $26.7 \%$ & $6.1 \%$ & $6.0 \%$ & $4.9 \%$ & $17.2 \%$ & $21.7 \%$ & $5.6 \%$ & $19.7 \%$ & $7.5 \%$ & $37.1 \%$ & $30.3 \%$ & $16.7 \%$ \\
\hline Rural & $49.6 \%$ & $22.1 \%$ & $17.2 \%$ & $37.1 \%$ & $8.2 \%$ & $8.1 \%$ & $6.7 \%$ & $24.2 \%$ & $28.7 \%$ & $8.0 \%$ & $28.3 \%$ & $11.1 \%$ & $52.2 \%$ & $41.3 \%$ & $24.6 \%$ \\
\hline Urban & $9.6 \%$ & $5.8 \%$ & $3.3 \%$ & $4.1 \%$ & $1.3 \%$ & $1.4 \%$ & $1.2 \%$ & $1.9 \%$ & $6.2 \%$ & $0.4 \%$ & $1.4 \%$ & $0.9 \%$ & $5.1 \%$ & $7.3 \%$ & $0.0 \%$ \\
\hline Pun & $31.2 \%$ & $12.0 \%$ & $8.9 \%$ & $24.3 \%$ & $3.1 \%$ & $4.7 \%$ & $2.7 \%$ & $10.1 \%$ & $18.3 \%$ & $4.0 \%$ & $16.6 \%$ & $1.8 \%$ & $31.9 \%$ & $25.4 \%$ & $13.3 \%$ \\
\hline Sind & $41.2 \%$ & $23.4 \%$ & $16.9 \%$ & $25.0 \%$ & $9.5 \%$ & $6.2 \%$ & $6.6 \%$ & $27.5 \%$ & $30.2 \%$ & $7.8 \%$ & $22.1 \%$ & $8.1 \%$ & $39.5 \%$ & $36.9 \%$ & $18.7 \%$ \\
\hline $\mathrm{KP}$ & $43.1 \%$ & $20.0 \%$ & $14.5 \%$ & $32.6 \%$ & $8.1 \%$ & $9.0 \%$ & $8.5 \%$ & $15.5 \%$ & $21.2 \%$ & $4.5 \%$ & $18.9 \%$ & $19.5 \%$ & $45.0 \%$ & $34.7 \%$ & $23.0 \%$ \\
\hline Balo & $67.1 \%$ & $36.6 \%$ & $31.3 \%$ & $46.0 \%$ & $18.9 \%$ & $11.8 \%$ & $11.5 \%$ & $57.4 \%$ & $22.4 \%$ & $18.4 \%$ & $48.8 \%$ & $37.5 \%$ & $63.5 \%$ & $43.9 \%$ & $28.5 \%$ \\
\hline \multicolumn{16}{|l|}{ 2014-15 } \\
\hline National & $35.2 \%$ & $16.6 \%$ & $12.2 \%$ & $23.4 \%$ & $7.7 \%$ & $6.8 \%$ & $6.5 \%$ & $15.5 \%$ & $21.3 \%$ & $5.6 \%$ & $22.1 \%$ & $7.0 \%$ & $35.1 \%$ & $26.2 \%$ & $15.8 \%$ \\
\hline Rural & $49.3 \%$ & $22.6 \%$ & $17.2 \%$ & $34.3 \%$ & $10.5 \%$ & $9.5 \%$ & $9.2 \%$ & $22.7 \%$ & $29.5 \%$ & $8.5 \%$ & $32.9 \%$ & $10.2 \%$ & $51.1 \%$ & $36.8 \%$ & $24.3 \%$ \\
\hline Urban & $8.9 \%$ & $5.5 \%$ & $2.9 \%$ & $3.0 \%$ & $2.4 \%$ & $1.8 \%$ & $1.5 \%$ & $2.1 \%$ & $6.1 \%$ & $0.4 \%$ & $1.8 \%$ & $1.1 \%$ & $5.3 \%$ & $6.5 \%$ & $0.0 \%$ \\
\hline Pun & $28.5 \%$ & $11.8 \%$ & $8.2 \%$ & $19.8 \%$ & $5.4 \%$ & $4.7 \%$ & $3.6 \%$ & $7.8 \%$ & $17.7 \%$ & $4.3 \%$ & $15.9 \%$ & $1.5 \%$ & $29.3 \%$ & $20.6 \%$ & $11.9 \%$ \\
\hline Sind & $39.1 \%$ & $22.0 \%$ & $16.4 \%$ & $23.2 \%$ & $8.5 \%$ & $7.9 \%$ & $9.5 \%$ & $26.1 \%$ & $29.9 \%$ & $7.7 \%$ & $30.0 \%$ & $7.1 \%$ & $37.9 \%$ & $33.9 \%$ & $19.6 \%$ \\
\hline KP & $43.9 \%$ & $19.3 \%$ & $14.7 \%$ & $32.1 \%$ & $11.2 \%$ & $9.9 \%$ & $9.6 \%$ & $13.4 \%$ & $19.8 \%$ & $3.6 \%$ & $20.5 \%$ & $19.6 \%$ & $44.8 \%$ & $31.4 \%$ & $22.4 \%$ \\
\hline Balo & $66.9 \%$ & $36.7 \%$ & $29.3 \%$ & $41.0 \%$ & $19.7 \%$ & $17.1 \%$ & $15.8 \%$ & $54.2 \%$ & $23.3 \%$ & $16.6 \%$ & $56.9 \%$ & $34.0 \%$ & $60.3 \%$ & $36.8 \%$ & $22.8 \%$ \\
\hline
\end{tabular}

Source: Statistical data is taken from PSLM (2016), Pakistan bureau of statistics Govt of Pakistan

NOTE: Where, \{YS (Years of schooling), SA (school attendance), EQ (Educational quality), HF (Access to health facilities), FM (Full care Assisted Immunization), AN

(Ante-Natal Care), AD(Assisted delivery), IW (Improved Walls), OC(overcrowding),EL(electricity),SN(Sanitation), WA(Water), CF(Cooking Fuel),AS(Assets),LN(Land \&Stock). Pun (Punjab), Sin (Sindh), KP (Khyber Pakhtunkhwan), Balo (Baluchistan)\}.

The deprivation rate of poor people (in\%) whom are fallen in each of the fifteen (15) indicators of MDPT irrespective of their status of poverty can be count in Uncensored head counts (UNCHD) ratios. Table (7) reports the UNCHD for time periods of 2012-13 to 2014-15;it is including the different factors with the highest and lowest levels of deprivation (in percentage). The results show that highest rate of deprivations are found in CF (cooking oil) with deprivation rate is60.6\% of population, YS (years of schooling) is found $48.5 \%$, total assets and overcrowding rate found (39.0\%) and (38.3\%) respectively. But on the other hand EL (without a supply of electricity) found6.4\%, deliveries of babies without the assistance of is $(8.2 \%)$. 
Table 7: Composition of Uncensored Headcount Ratios (\%) of Pakistan

\begin{tabular}{|c|c|c|c|c|c|c|c|c|c|c|c|c|c|c|c|}
\hline $2012-13$ & YS & SA & EQ & $\mathrm{HF}$ & FM & AN & $\mathrm{AD}$ & IW & $\mathrm{OC}$ & EL & SN & WA & $\mathrm{CF}$ & AS & $\mathrm{LN}$ \\
\hline National & $49.0 \%$ & $18.8 \%$ & $18.6 \%$ & $38.8 \%$ & $8.0 \%$ & $8.3 \%$ & $6.4 \%$ & $21.2 \%$ & $37.2 \%$ & $6.6 \%$ & $23.8 \%$ & $10.7 \%$ & $63.1 \%$ & $45.2 \%$ & $28.4 \%$ \\
\hline Rural & $59.1 \%$ & $23.3 \%$ & $22.6 \%$ & $51.1 \%$ & $9.7 \%$ & $10.3 \%$ & $8.1 \%$ & $28.8 \%$ & $40.0 \%$ & $8.8 \%$ & $33.8 \%$ & $14.1 \%$ & $86.3 \%$ & $55.1 \%$ & $42.4 \%$ \\
\hline Urban & $26.8 \%$ & $8.8 \%$ & $11.5 \%$ & $11.7 \%$ & $4.2 \%$ & $4.2 \%$ & $3.1 \%$ & $4.8 \%$ & $30.0 \%$ & $1.7 \%$ & $2.8 \%$ & $5.3 \%$ & $17.5 \%$ & $25.9 \%$ & $0.0 \%$ \\
\hline Pun & $43.3 \%$ & $13.5 \%$ & $15.3 \%$ & $40.5 \%$ & $5.0 \%$ & $7.2 \%$ & $4.0 \%$ & $12.6 \%$ & $34.7 \%$ & $4.9 \%$ & $21.1 \%$ & $4.9 \%$ & $64.2 \%$ & $42.2 \%$ & $27.1 \%$ \\
\hline Sind & $53.2 \%$ & $26.1 \%$ & $22.2 \%$ & $29.9 \%$ & $11.5 \%$ & $7.7 \%$ & $8.3 \%$ & $32.3 \%$ & $47.5 \%$ & $8.7 \%$ & $24.9 \%$ & $10.1 \%$ & $51.2 \%$ & $49.6 \%$ & $23.5 \%$ \\
\hline $\mathrm{KP}$ & $56.2 \%$ & $22.1 \%$ & $20.3 \%$ & $42.1 \%$ & $9.9 \%$ & $12.3 \%$ & $10.8 \%$ & $21.4 \%$ & $33.6 \%$ & $5.5 \%$ & $22.0 \%$ & $24.8 \%$ & $73.9 \%$ & $48.6 \%$ & $39.6 \%$ \\
\hline Balo & $75.7 \%$ & $38.1 \%$ & $35.6 \%$ & $51.8 \%$ & $20.1 \%$ & $13.3 \%$ & $12.5 \%$ & $69.3 \%$ & $28.5 \%$ & $18.9 \%$ & $56.4 \%$ & $41.0 \%$ & $76.2 \%$ & $49.8 \%$ & $33.9 \%$ \\
\hline \multicolumn{16}{|l|}{ 2014-15 } \\
\hline National & $48.5 \%$ & $18.5 \%$ & $17.7 \%$ & $32.4 \%$ & $14.0 \%$ & $9.1 \%$ & $8.2 \%$ & $18.5 \%$ & $38.3 \%$ & $6.4 \%$ & $27.1 \%$ & $10.9 \%$ & $60.6 \%$ & $39.0 \%$ & $28.0 \%$ \\
\hline Rural & $60.0 \%$ & $23.8 \%$ & $21.8 \%$ & $45.5 \%$ & $15.6 \%$ & $11.6 \%$ & $10.7 \%$ & $26.2 \%$ & $41.4 \%$ & $9.2 \%$ & $39.8 \%$ & $12.7 \%$ & $84.4 \%$ & $47.4 \%$ & $43.0 \%$ \\
\hline Urban & $27.1 \%$ & $8.5 \%$ & $10.1 \%$ & $7.9 \%$ & $11.1 \%$ & $4.5 \%$ & $3.3 \%$ & $4.1 \%$ & $32.4 \%$ & $1.3 \%$ & $3.4 \%$ & $7.6 \%$ & $16.2 \%$ & $23.2 \%$ & $0.0 \%$ \\
\hline Pun & $42.7 \%$ & $13.3 \%$ & $13.9 \%$ & $30.7 \%$ & $13.2 \%$ & $7.0 \%$ & $5.1 \%$ & $9.6 \%$ & $36.8 \%$ & $5.2 \%$ & $20.5 \%$ & $4.3 \%$ & $61.8 \%$ & $34.7 \%$ & $27.0 \%$ \\
\hline Sin & $50.4 \%$ & $24.5 \%$ & $21.6 \%$ & $28.3 \%$ & $12.5 \%$ & $9.5 \%$ & $11.2 \%$ & $29.6 \%$ & $47.7 \%$ & $8.3 \%$ & $35.5 \%$ & $12.1 \%$ & $47.6 \%$ & $46.2 \%$ & $25.0 \%$ \\
\hline $\mathrm{KP}$ & $59.0 \%$ & $21.1 \%$ & $20.4 \%$ & $41.2 \%$ & $16.8 \%$ & $13.1 \%$ & $11.7 \%$ & $17.6 \%$ & $30.7 \%$ & $3.9 \%$ & $23.9 \%$ & $25.7 \%$ & $74.3 \%$ & $42.3 \%$ & $37.7 \%$ \\
\hline Balo & $74.9 \%$ & $38.5 \%$ & $34.1 \%$ & $46.9 \%$ & $22.6 \%$ & $19.3 \%$ & $17.6 \%$ & $65.5 \%$ & $29.0 \%$ & $17.6 \%$ & $67.6 \%$ & $39.1 \%$ & $74.4 \%$ & $41.5 \%$ & $27.4 \%$ \\
\hline
\end{tabular}

Source: Statistical data taken from PSLM (2016).Pakistan bureau of statistics Govt of Pakistan. 


\section{Trends and overtime changes in Multidimensional poverty in Pakistan}

The level of poverty (table8) rose during the period of 1992/93to2001/02 except the year of 1996/97, and then dropped quickly 10.6 percentage points after the periods of 2001/02 (34.5\%) to 2004/05(23.9\%). These figures caused a huge disturbance at that time in the civil society, national press and amongst development experts in Pakistan. According to statistical survey of Pakistan HD was found17.2 percentin2007-08 and which meant that the proportion of deprivation had declined a furthermore 5.1percent declined found in between 2005-06 and 2007-08, when the HD reduced further to 12.4percent (Government of Pakistan,2014).

Table 8: Overtime changes in Multidimensional poverty / based on poverty line (official)

\begin{tabular}{|l|l|l|l|l|l|l|l|l|l|}
\hline & \multicolumn{3}{|l}{ Head count ratio of poverty } & \multicolumn{3}{l|}{ Poverty gap } & \multicolumn{3}{l|}{ Extreme level of poverty } \\
\hline & Urban & Rural & Total & Urban & Rural & Total & Urban & Rural & Total \\
\hline $1992-93$ & $20.0 \%$ & $27.6 \%$ & $25.5 \%$ & $3.4 \%$ & $4.6 \%$ & $4.3 \%$ & $0.9 \%$ & $1.2 \%$ & $1.1 \%$ \\
\hline $1993-94$ & $15.9 \%$ & $33.5 \%$ & $28.2 \%$ & $2.7 \%$ & $6.3 \%$ & $5.2 \%$ & $0.7 \%$ & $1.8 \%$ & $1.4 \%$ \\
\hline $1996-97$ & $15.8 \%$ & $30.2 \%$ & $25.8 \%$ & $2.4 \%$ & $5.3 \%$ & $4.4 \%$ & $0.6 \%$ & $1.4 \%$ & $1.1 \%$ \\
\hline $1998-99$ & $20.9 \%$ & $34.7 \%$ & $30.6 \%$ & $4.3 \%$ & $7.6 \%$ & $6.4 \%$ & $1.3 \%$ & $2.4 \%$ & $2.0 \%$ \\
\hline $2001-02$ & $22.7 \%$ & $39.3 \%$ & $34.5 \%$ & $4.6 \%$ & $8 \%$ & $7 \%$ & $1.4 \%$ & $2.4 \%$ & $2.1 \%$ \\
\hline $2004-05$ & $14.9 \%$ & $28.1 \%$ & $23.9 \%$ & $2.9 \%$ & $5.6 \%$ & $4.8 \%$ & $0.8 \%$ & $1.8 \%$ & $1.5 \%$ \\
\hline $2005-06$ & $13.1 \%$ & $27.0 \%$ & $22.3 \%$ & $2.1 \%$ & $5.0 \%$ & $4.0 \%$ & $0.5 \%$ & $1.4 \%$ & $1.1 \%$ \\
\hline $2007-08$ & $10.0 \%$ & $20.6 \%$ & $17.2 \%$ & - & - & - & - & - & - \\
\hline $2010-11$ & $7.1 \%$ & $15.1 \%$ & $12.4 \%$ & & & & & & \\
\hline
\end{tabular}

Source: Cheema (2005) \& Government of Pakistan (2014) Pakistan bureau of Pakistan.

Table (9) shows the incidence of head count ratio (HD), intensity of poverty (IA) and level of MDPT as the three main three key statistics for measurement of poverty. Results indicate that these three statistics have changed over periods of 2004 to 2015 which include four provinces. The ratio of multidimensional poverty has been decreased slowly between the periods of 2004 and 2015 and it is also evident in results that the rate of decrease found statistically significant also. The results of MDPT are shown decline from 0.292 points in the period of 2004-05 to 0.197 points in 2014-15, while the ratio of headcount (H) dropped from $55.2 \%$ to $38.8 \%$ ( $16.4 \%$ is difference). But the average intensity (IA) rate is declined strikingly very little, from $52.9 \%$ to $50.9 \%$. Nevertheless, the results found positive and significant change in poverty reduction rate in terms of MDPT ratio or HD*IA between 2004-05 and 2014-15.

Table9:Overtime changes in HD, IA and the MDPT, 2004-2015

\begin{tabular}{|l|l|l|l|}
\hline $\mathrm{Kt}=33 \%$ (Cut-off) & HD*IA or MDPT (\%) & HD $(\%)$ & IA (\%) \\
\hline $2004-05(\mathrm{I})$ & 0.292 & 55.2 & 52.9 \\
\hline $2006-07$ & 0.281 & 52.5 & 53.4 \\
\hline $2008-09$ & 0.26 & 49.3 & 52.6 \\
\hline $2010-11$ & 0.228 & 44.7 & 51 \\
\hline $2012-13$ & 0.207 & 40.8 & 50.7 \\
\hline $2014-15$ (II) & 0.197 & 38.8 & 50.9 \\
\hline Change, 2004 (I) to 2015 (II) & $0.095^{* * *}$ & $0.164^{* * *}$ & $0.020^{* * *}$ \\
\hline SE (aggregate) & 0.0052 & 0.0091 & 0.0025 \\
\hline Hypothesis testing & 18.16 & 17.99 & 8.08 \\
\hline p-(value) & 0.000 & 0.000 & 0.000 \\
\hline
\end{tabular}

Source: Authors' estimation constructed on data from various issues of the PSLM statistical surveys. 
*** Denotes $1 \%$ level of significance.

The intensity of derivation of the poor population is depicted in pie chart below (figure 2), the deprivation intensities range start from than $33.3 \%$ to less than $40 \%$. These groups with different ranges showed the intensity of poor people in percentage.

\section{Intensity (IA) Deprivation}

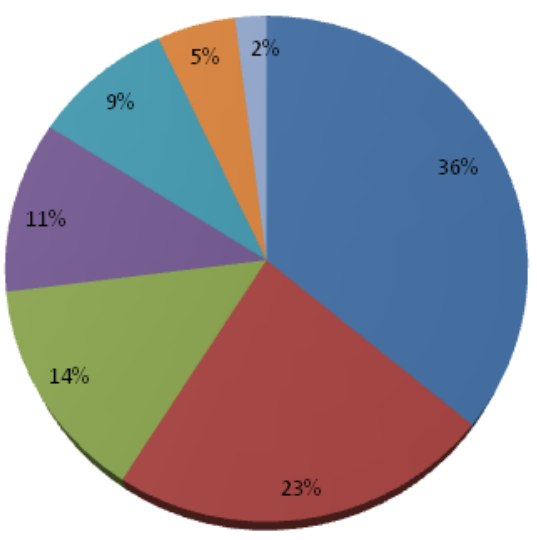

$33.3 \%-39.9 \%$

$40 \%-49.9 \%$

$50 \%-59.9 \%$

$60 \%-69.9 \%$

$-70 \%-79.9 \%$

$80 \%-89.9 \%$

$90 \%-100 \%$

Figure 2: Intensity (IA) Deprivation

\section{Significant change in headcount $(H)$ for all four Provinces}

The results of head count ratio and multidimensional poverty incidence over time across provinces are reported in table10. The changes between different years 2004-05 / 2014-15 and 2014 also compared with 2004 in this analysis. The results of Punjab across all years are showed reduction in terms of HD and MDPT prospective and also found significant reduction in whole country (2004 to 2015), a significant drop can be seen in MDPT for province Sindh, from 2008-10, and 2006-08. The statistical figures of KPK show an increasing and decreasing trend in both HD and MDPT ratios. The significant drop between the periods of 2006 and 2012 can be observed in HD and MDPT, and a reduction between 2004 and 2014 also found significant. The poverty in Baluchistan is higher as compared to other provinces, only one significant change in MDPT found between 2008 and 2010. Though, HD and MDPT have significantly decreased over the years of 2004 to 2014.

Table 10: Change in Headcount for All Provinces (with statistical significance)

\begin{tabular}{|l|l|l|l|l|l|l|l|}
\hline Province & Years & $\begin{array}{l}\text { Change in } \\
\text { HD }\end{array}$ & $\begin{array}{l}\text { Change in } \\
\text { MDPT }\end{array}$ & Province & Years & $\begin{array}{l}\text { Change in } \\
\text { HD }\end{array}$ & $\begin{array}{l}\text { Change in } \\
\text { MDPT }\end{array}$ \\
\hline PUN & $\begin{array}{l}2014- \\
2012\end{array}$ & $-0.03288^{* *}$ & $0.01649^{* *}$ & KPK & $2014-2012$ & 0.00094 & 0.00051 \\
\hline & $\begin{array}{l}2012- \\
2010\end{array}$ & $-0.0339 * *$ & $-0.01984^{* *}$ & & $2012-2010$ & $-0.05931^{* *}$ & $-0.03129 * *$ \\
\hline & $\begin{array}{l}2010- \\
2008\end{array}$ & $-0.0516^{* *}$ & $-0.03037^{* *}$ & & $2010-2008$ & $-0.05431^{* *}$ & $-0.04052^{* *}$ \\
\hline & $\begin{array}{l}2008- \\
2006\end{array}$ & $-0.03221^{* *}$ & $-0.02019^{* *}$ & & $2008-2006$ & $-0.05638^{* *}$ & $-0.02955^{*}$ \\
\hline & $2006-$ & $-0.03296^{* *}$ & $-0.01519^{*}$ & & $2006-2004$ & 0.00271 & -0.00007 \\
\hline
\end{tabular}




\begin{tabular}{|l|l|l|l|l|l|l|l|}
\hline & 2004 & & & & & & \\
\hline & $\begin{array}{l}2014- \\
2004\end{array}$ & $-0.18353^{* *}$ & $-0.10208^{* *}$ & & $2014-2004$ & $-0.16635^{* *}$ & $-0.10092^{* *}$ \\
\hline SIN & $\begin{array}{l}2014- \\
2012\end{array}$ & -0.01441 & -0.00523 & BALO & $2014-2012$ & -0.00688 & -0.01008 \\
\hline & $\begin{array}{l}2012- \\
2010\end{array}$ & $-0.0344^{*}$ & -0.01635 & & $2012-2010$ & -0.04015 & -0.01143 \\
\hline & $\begin{array}{l}2010- \\
2008\end{array}$ & $-0.03234 *$ & $-0.02714^{* *}$ & & $2010-2008$ & -0.03012 & $-0.04371^{* *}$ \\
\hline & $\begin{array}{l}2008- \\
2006\end{array}$ & -0.02448 & $-0.02282^{*}$ & & $2008-2006$ & -0.00873 & -0.01183 \\
\hline & $\begin{array}{l}2006- \\
2004\end{array}$ & $-0.03568^{*}$ & -0.01452 & & $2006-2004$ & -0.03584 & -0.0075 \\
\hline
\end{tabular}

* Significant at $5 \%$ significance level

** Significant at $1 \%$ significance level

Source: authors' own estimation constructed on statistical data from PSLM statistical surveys, Pakistan bureau of statistics, Govt of Pakistan.

\section{Discussion}

The "No Poverty" in all its dimensions everywhere by 2030 is one of the main Goal of Sustainable Development Goals. The vision 2025 of Pakistan also based on poverty reduction in terms of "No left behind" but at the same time it stances the challenges of eliminating poverty in all its dimensions and from all regions of Pakistan.

Some countries such as Mexico and Colombia have been incorporated social action program into the poverty reduction programs (Angulo et al. 2016 and Coneval 2007). In 1980s, the Government of Pakistan launched poverty reduction program though mainly concentrating the basic necessities of life e.g., health, education, clean drinking water and etc. Government launched different social safety net programs for poverty reduction as cash money transfer the Benazir Income Support Program, Pakistan Bait ulul-Mal, Workers Welfare Fund (WWF), Pakistan Micro finance network and another social welfare program for old people s Employees Old Age Benefit Institution.

The result of these schemes to overcome the problem of poverty is not beneficial in the rural as well as in urban areas. Poverty in Pakistan cannot overcome the problem of poverty with its all dimension because as corruption and wrong implementation of social action programs, high rate of terrorism attacks, high rate population, regional disparities, political instability, energy crises and dearth of effective targeting. Reductions of socioeconomic deprivations are prerequisite for the sustainable living. Pakistan as developing country couldn't achieve the required targets from these social action programs, so education is important indicator which can be removed poverty and poverty gap from economy efficiently, in addition poverty gap between urban and rural regions can be reduced by provide more educational facilities to rural regions as well. Higher education and technical education is directly effect on poverty reduction with creation of job opportunities but the health and house facilities are also important in poverty reduction. The worse health facilities have been associated with higher rate of poverty. Poverty alleviation programs should be properly implemented to improve all three dimensions.

\section{Conclusions}

This article is based on poverty with its different shapes in terms of the regional variations including four provinces, rural and urban regions of Pakistan. Applying Alkire-Foster methodology with Global Multidimensional Poverty Index standard, the results shows the increasing trend in between 2010/11 and 
2012/13.The results at provincial level indicate that Balochistan found higher rate of poverty with its all dimensions while Punjab has the lowest incidence.

This empirical analysis provides that an integrating technique adopting for MDPT to overcome the socioeconomic issues rapidly in Pakistan because it is basic requirement of millennium development goals (MDG's) to provide basic necessities of life (e.g., food, health, water, and education) to meet the Global standards of wellbeing. The policies based on poverty alleviation from Pakistan there are some steps have been taken by government especially the regions with higher level of poverty, and trying to the quality of primary and secondary education through growing number of schools and teachers, by increasing school enrollment ratio, and providing some inducements of scholarships and try to compensate various poor families with money and send their children to school. The Government may provide high quality with technical education such as knowledge and skills which can be contributed to economic growth and development (also supported by Khilji (2014, 2015). Pakistan is an agriculture based country so provide opportunities in terms of providing agriculture credit with easy process, subsidized pesticides, seeds and cheap availability of gas and electricity, proper infrastructure than the these areas may also can be control on poverty. Similarly, health facilities should be increased in rural areas especially, by providing them well-resourced hospitals, including trained doctors and other paramedical staff and to check their efficiency there should be a proper system which indorsing the proper monitoring.

Further, easy access and free entry to the technical schools particularly for poor pupils may also raise the chances of income by providing skills to start non-farm earning initiatives (Chawanote \& Barrett, 2012). The multidimensional poverty in rural areas of Pakistan, receiving opportunities in the agriculture sector may also be enhanced through providing easy access to suitable credit, subsidized inputs and needed extension services. Similarly, health facilities should be increased in rural areas, particularly through increasing the number of wellresourced hospitals along with suitable trained staff and confirming the proper monitoring of their working efficiency mostly in the rural part of the population.

Thus escalating social protection schemes and pursuing appropriate programs to the poor and most vulnerable can further decrease poverty. Social protection programs based on particularly cash transfers programs, school feeding schemes and, improvement in labor market, as well as social and unemployment insurance and, adding old-age pensions, skills training, disability pensions, and wage subsidies, among others. Moreover, the suggestion of this study to adopt those policy mechanisms which is beneficial for poverty alleviation, developing countries can also follow these suggestions to overcome the problem of poverty.

\section{References}

Ahluwalia, M. S. (2011). Prospects and Policy Challenges in the Twelfth Plan.Economic and Political Weekly, 46(21), 88-105.

Alkire, S., \& Foster, J. (2008).Counting and multidimensional poverty measures. Oxford Poverty and Human Development Initiative (OPHI), Working Paper 7. Oxford Department of International Development, University of Oxford. http://www.ophi.org.uk/wp-content/uploads/ophi-wp7.pdf.

Alkire, S., \& Santos, M.E. (2010). Acute multidimensional poverty: A new index for developing countries. Oxford University \& Human Development Initiative (OPHI).

Alkire, S., \& Foster, J. (2011).Counting and multidimensional poverty measures. Journal of Public Economics 95(7-8), 476-487.

Alkire, S., Foster, J., Seth, S., Santos, M. E., Roche, J. M., \&Ballon, P. (2015). Multidimensional poverty measurement and analysis: Chapter 6-Normative choices in measurement design.

Alkire.S., and Shen, Y. (2017). Exploring Multidimensional Poverty in China: 2010 to 2014.Oxford University \& Human Development Initiative (OPHI). 
Alkire.S., and Robles. G. (2017).Global Multidimensional Poverty Index 2017.Oxford University \& Human Development Initiative (OPHI).

Angulo, R., Diaz, Y., \&Pardo, R. (2016). The Colombian multidimensional poverty index: Measuring poverty in a public policy context. Social Indicators Research, 127, 1-38.

Batana, Y. M. (2013). Multidimensional measurement of poverty among women in Sub-Saharan Africa. Social Indicators Research, 112(2), 337-362. doi:10.1007/s11205-013-0251-9.

Bourguignon, F., \&Chakravarty, S.R. (2003).The measurement of multidimensional poverty. Journal of Economic Inequality, 1, 25-49.

Battiston, D., Cruces, G., Lopez-Calva, L. F., Lugo, M. A., \& Santos, M. E. (2013). Income and beyond: multidimensional poverty in six Latin American countries. Social Indicators Research, 112(2), 291314.doi:10.1007/s11205-013-0249-3.

Cheema, Iftikhar Ahmed (2005).A Profile of Poverty in Pakistan. Centre for Research on Poverty Reduction and Income Distribution Planning Commission, Islamabad.

CPRC. (2004). The chronic poverty report 2004-05. UK: Chronic Poverty Research Centre.

Coneval. (2007). Multidimensional measurement of poverty in Mexico: an economic wellbeing and social rights approach, Mexico. http://www.coneval.org.mx/InformesPublicaciones/ FolletosInstitucionales/Documents/Multidimensional-Measurement-of-poverty-in-Mexico.pdf.

Chawanote, C., \& Barrett, C. B. (2012). Non-farm occupational and earning dynamics in rural Thailand. Charles H. Dyson School of Applied Economics and Management., Working paper of Cornell University, United States of America, http://dyson. cornell.edu/faculty sites/cbb2/Papers/Paper1Namtip revisedNT Sep30\%20(1). Pdf (retrieved 21.01.13)

Coromaldi, M., \&Zoli, M. (2012). Deriving multidimensional poverty indicators: Methodological issuesand an empirical analysis for Italy. Social Indicators Research, 107(1), 37-54. doi:10.1007/s11205011-9825-6.

Decancq, K., \& Lugo, M. A. (2013). Weights in multidimensional indices of wellbeing: An overview.

Econometric Reviews, 32(1), 7-34.

Decancq, K., \& Lugo, M. A. (2013). Weights in multidimensional indices of wellbeing: An overview.

Econometric Reviews, 32(1), 7-34.

Foster, J. (2007). A report of Mexican multidimensional poverty measurement. Oxford Poverty \& Human Development Initiative (OPHI), Working Paper No. 40.

Government of Pakistan (2014).Economic Survey 2013-14.Ministry of Finance. Islamabad.

Government of Pakistan (2016). Pakistan Social and Living Standards Measurement Survey (PSLMS), Pakistan Bureau of Statistics (PBS), Government of Pakistan.

Haq, R., \&Bhatti, M. A. (2001). Estimation of poverty in Pakistan: The non-food con- sumption approach. Research report No. 183.

Hanandita, W., \&Tampubolon, T. (2015). Multidimensional poverty in Indonesia: Trend over the last decade (2003-2013). Social Indicators Research, 128, 1-29.

Hussain, A., \&Routray, J. K. (2012).Status and factors of food security in Pakistan.International Journal of Development Issues, 11(2), 164-185.

Idrees, M., Mohsin, A., \&Zaman, K. (2012). Welfare impacts of food price inflation in Pakistan. International Food ResearchJournal, 19(4),1517-1531.

Jayaraj, D., \& Subramanian, S. (2010). A Chakravarty-D'Ambrosio view of multidimensional deprivation: some estimates for India. Economic and Political Weekly, 53-65.

Khan, M. A. (2003). Public expenditure, poverty and human development: The experience of Pakistan. In Pakistan human condition report 2003. Islamabad: CentreFor Research on Poverty Reduction and Income Distribution (CRPRID) and UNDP.

Khan, A. U., Saboor, A., Hussain, A., Karim, S., \&Hussain, S. (2015). Spatial and temporal investigation of multidimensional poverty in rural Pakistan.Poverty \& Public Policy, A Global Journal of Social Security, Income Aid and Welfare, 7(2), 158-175.

Khilji,B(2014).HRD in Pakistan an analytical study, lambert publisherswesteren Germany 
Khilji,B (2015). 60 years of Human resource Development in Pakistan ,Published by Higher Education Commissionsecond edition Islamabad Pakistan.

Kruijk, H. D., \&Rutten, M. (2007). Weighting dimensions of poverty based on people's priorities: Constructing a composite poverty index for Maldives Discussion Paper: 2007-8(01). Institute of International \& Development Economics.

Saboor, A., Khan, A. U.,Hussain,A., ALI,A.,\&Mahmood, K.(2015). Multidimensional deprivations in Pakistan: Regional variations and temporal shifts. The Quarterly Review of Economics and Finance 56 (2015) 57-67

Lipton, M. (1997). Editorial: Poverty-Are the holes in the consensus. World Development, 25(7), $1003-1006$.

Misturelli, F., \& Heffernan, C. (2010). The concept of poverty a synchronic perspective. Progress in Development Studies, 10(1), 35-58.

Mishra, U. S., \&Shukla, V. (2016). Welfare comparisons with multidimensional well-being indicators: AnIndian illustration. Social Indicators Research, 129(2), 505-525.

Mohanty, S. K. (2011). Multidimensional poverty and child survival in India.PLoS ONE 6(10): e26857.

http://www.plosone.org/article/fetchObject.action?uri=info:doi/10.1371/journal.pone.

0026857\&representation=PDF.

Mohanty, S, K,.Rasul, G,.Mahapatra, B,.Choudhury, D,.Tuladhar, S,. Holmgren, E. V,. (2017) Multidimensional Poverty in Mountainous, Regions: Shan and Chin in Myanmar, Social Indicators Research $(1-22)$

Naveed, A., \& Islam, T. (2010). Estimating multidimensional poverty and identifying the poor in Pakistan: An alternative approach. RECOUP Working Paper Series No. 28.

Naseem, S.M. (2012). A review of studies on poverty in Pakistan: Origin, evolution, thematic content and future directions. History of PIDE Series-6. (Dr. Rashid, Amjad Ed.). Islamabad: Pakistan Institute of Development Economics. ISBN 978-969-461-145-7.

Noble, M., Barnes, H., Wright, G., \& Roberts, B. (2009). Small area indices of multiple deprivation in Africa. UK: Department of Social Policy and Social Work, University of Oxford.

Ravallion, M. (2011b). On Multidimensional Indices of Poverty.Worldbank Policy Reseach WorkingPaper, WPS5580. Cite JEI version - Journal of economic inequality;

Rippin, N. (2010). Poverty severity in a multidimensional framework: The issue of inequality between dimensions (No. 47). Courant Research Centre: Poverty, Equity, and Growth-Discussion Papers.

Santos, M. E. (2013). Tracking poverty reduction in Bhutan: income deprivation alongside deprivation in other sources of happiness. Social Indicators Research, 112(2), 259-290. doi:10.1007/s11205-013-0248-4.

Sen, A.K. (1999). Development as freedom. Oxford: Oxford University Press. ISBN: 0198297580.

Sahn, D. E., \&Stifel, D. C. (2000). Poverty comparisons over time and across countries in Africa.World Bank WorldDevelopment, 28, 2123-2155.

UN Millennium Project. (2002). Fast facts: The faces of poverty. http://www. unmilleniumproject.org/documents/3-MP-PovertyFacts-E.pdf (retrieved 07.11.10)

UNDP (2010). Human development report 2010. United Nations Development Programme (20 ${ }^{\text {th }}$ Anniversary Edition). New York: The United Nations.

UNDP (2013). Human development report 2013. The rise of the south: Human progress in a diverse world. New York: United Nations Development Programme.

World Bank. (2002). Pakistan poverty assessment. Poverty reduction and economic management sector, Unit South Asia Region. Report No. 24296-PAK.

World Bank (2011). World development indicators.Washington,D.C:World Bank 